\title{
Antitissue antibodies in monozygotic twins with systemic lupus erythematosus
}

\author{
E. J. JOKINEN AND E. O. JÄNK ÄLÄ \\ From the Department of Serology and Bacteriology and the Second Medical Clinic, University of Helsinki, \\ Helsinki, Finland
}

The familial occurrence of systemic lupus erythematosus (SLE) is well established (Brunjes, Zike, and Julian, 1961; Leonhardt, 1964), and even monozygotic twins with this disease have been reported by several workers (Davis and Gutridge, 1951; Wagenhals and Burgeson, 1958; Blumenfeld, Kaplan, Mills, and Clark, 1963; Joseph and Zarafonetis, 1965; Lieberman, Heuser, Hanson, Kornreich, Donnell, and Landing, 1968). These observations have been considered to indicate that genetically determined factors may have an important role in the aetiology of SLE. The following is a report of a pair of monozygotic twins both of whom had SLE with a very similar clinical picture and who, in addition, had a very similar antitissue antibody pattern.

\section{Case reports}

Case 1, a 33-year-old housewife, mother of three children, was sent to hospital for pyrexia, arthralgia, and loss of weight. She had a childhood history of frequently recurring tonsillitis. When 6 years of age she had had scarlet fever, with accompanying carditis, from which she made a good recovery. Arthralgia, especially in the fingers, wrists, elbow joints, and ankles had continued for nearly 10 years. The persistent rash on the patient's

palms and on the volar aspect of the fingers had appeared 8 years before admission, followed a little later by a papular facial eruption (Figure). Exposure to sunlight distinctly aggravated both the joint and skin symptoms, and handling of turpentine made the skin symptoms worse. For the last 6 months there had been episodes of discoloration of the fingers, and pale insensible patches appeared on the skin of the palms under the influence of both cold and heat. These episodes had lasted a few hours at a time. Treatment with gold and butazolidin had been instituted 6 months before admission to hospital for a supposed diagnosis of rheumatoid arthritis. The patient's general condition had subsequently deteriorated rapidly, the symptoms had become exacerbated, and she had lost $10 \mathrm{~kg}$. in weight, for which reasons therapy had been discontinued.

\section{Examination}

The patient's general condition was found to be poor. She weighed only $43 \mathrm{~kg}$. and had a low fever. Tenderness, swelling, and some limitation of movement was present in most joints of the extremities. There was a facial rash of the papular type (Figure). A systolic murmur of second grade was heard from the heart, most distinctly from its base. Nothing pathological was seen in the electrocardiogram or in $x$-ray examinations of the chest, stomach, and colon. Blood tests disclosed slight sideropenic anaemia, which was corrected rapidly by

Address for reprints:

Dr. E. J. Jokinen, M.D., Department of Serology and Bacteriology, University of Helsinki, Haartmaninkatu 3, Helsinki 25, Finland.

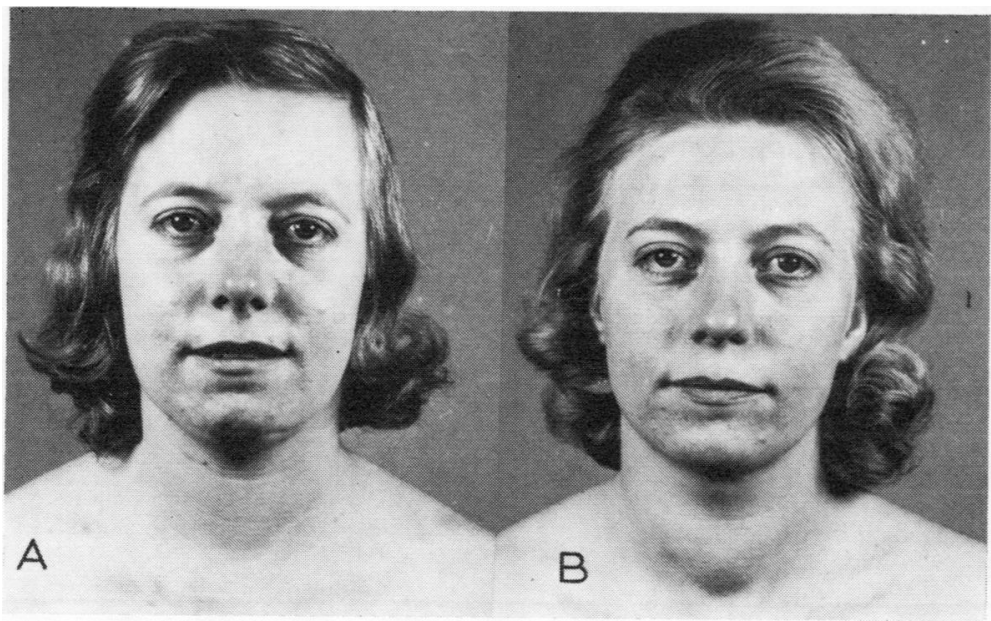

FIGURE Case 1(A) and Case 2(B) before the institution of steroid therapy. 
iron therapy, and mild leucopenia (3000/cu. mm.). The erythrocyte sedimentation rate was markedly elevated, and hypergammaglobulinaemia was considerable. Urinalysis showed nothing pathological.

Case 2, an unmarried beautician, was invited to the hospital for examination after SLE had been diagnosed in her twin sister. She presented an amazingly similar history. The symptoms were those described above, and even the dates of their onset were approximately the same. The patient weighed $53 \mathrm{~kg}$. and showed a better general condition than her twin, perhaps because she had had no gold therapy. Otherwise the hospital examinations gave similar results.

The patients looked very much alike (Figure). In blood grouping the phenotypes were identical: $\mathrm{A}_{1} \mathrm{~B}$, MN, CcDd, Tf C, Hp 1-1, Gc 2-1, Gm a $\mathrm{x}^{+} \mathrm{b}^{+}$.

The patients' parents were living and felt well. There were no other children in the family. The mother's nephew had died at the age of 12 with acute articular symptoms, and several other relations had had mild articular complaints. No joint diseases had occurred in the father's family.

\section{Investigations}

Antibodies to the following tissue antigens were determined before the institution of steriod therapy:

CELL NUCLEI

Cryostat sections of rat liver fixed in ethanol were used as the source of nuclei. Antibodies were studied by the indirect immunofluorescent technique (Friou, 1967).

DEOXYRIBONUCLEOPROTEIN

The method was latex agglutination, using a commercially-prepared set (Hyland Laboratories, Eurobiochim S.A., Div. Hyland, Brussels, Belgium).

DEOXYRIBONUCLEIC ACID

A passive haemagglutination method with the antigen coupled to formalized erythrocytes was used (Jokinen and Julkunen, 1965).

\section{HEART EXTRACT IN SALINE}

The method was a passive haemagglutination as described by Boyden and modified by Gery and Davies (1961). The antigen was prepared from human hearts obtained within a few hours after death from the victims

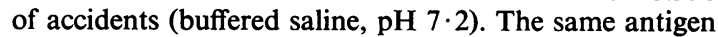
was used to assay the antibodies also with the complementfixation technique according to Gery and Davies (1961).

\section{HEART EXTRACT IN ETHANOL}

The antigen was prepared by mixing human ground heart muscle obtained post mortem in a 9-fold quantity of 96 per cent. ethanol $(\mathrm{w} / \mathrm{v})$. The mixture was kept at $56^{\circ} \mathrm{C}$. for 2 hours and then at room temperature overnight, after which it was filtered and $0 \cdot 1$ per cent. cholesterol was added to it. The antibodies were studied by the one-fifth volume Kolmer Test (U.S. Department of Health, Education and Welfare, 1959).

\section{THYROGLOBULIN}

The method employed was passive haemagglutination described by Roitt and Doniach (1958).

THYROID MICROSOMAL ANTIGEN

Antibodies were determined with the complementfixation method described by Roitt and Doniach (1958).

\section{ERYTHROCYTES}

Both direct and indirect Coomb's technique was used.

A series of 2-fold dilutions was made of the sera, except when passive haemagglutination was employed to determine antibodies to heart extract in saline and thyroglobulin. 10 -fold dilutions beginning with $1: 25$ were used. The sera of both patients were examined in parallel at least five times with known positive and negative controls. The result varied slightly on different occasions, but generally, in the same way for both patients. The reading most frequently obtained was entered as the final result. In addition, the LE-cell test was performed.

\section{Results}

The levels of antibodies to the tissue antigens mentioned above are given in the Table. They were the

Table Antitissue antibodies in monozygotic twins with SLE

\begin{tabular}{|c|c|c|c|}
\hline \multirow[t]{2}{*}{ Antigen } & \multirow[t]{2}{*}{ Method } & \multicolumn{2}{|c|}{ Antibody titre } \\
\hline & & Case 1 & Case 2 \\
\hline Cell nuclei & Immunofluorescence & 2048 & 2048 \\
\hline Deoxyribonucleoprotein & Latex agglutination & 128 & 128 \\
\hline Deoxyribonucleic acid & Passive haemagglutination & 256 & 256 \\
\hline Heart extract in saline & Complement-fixation & 64 & 64 \\
\hline Heart extract in saline & Passive haemagglutination & 25000 & 25000 \\
\hline Heart extract in ethanol & Complement-fixation & 32 & 32 \\
\hline Thyroglobulin & Passive haemagglutination & 0 & 0 \\
\hline Thyroid microsomal & Complement-fixation & $\mathbf{0}$ & $\mathbf{0}$ \\
\hline Erythrocytes & Coombs technique & $\mathbf{0}$ & 0 \\
\hline
\end{tabular}


same for both patients, with the exception of the heart antibodies obtained by passive haemagglutination with saline extract as the antigen. Even then the difference was merely one dilution step. The LE-cell phenomenon was pronounced in both twins.

Some other antibody levels displayed a considerable difference. The rheumatoid factor titre was $\mathbf{3 0}$ for Patient 1 and 120 for Patient 2. The ASO value for Patient 1 was $80 \mathrm{IU}$ and ASTA 0.5 IU. The corresponding values for Patient 2 were $40 \mathrm{IU}$ and 2.0 IU. The Kahn, Kolmer, and Reiter protein complement-fixation tests were non-reactive in both patients. The antitissue antibody values of the parents w'ere negative by all the methods used.

\section{Discussion}

It seems quite plausible that the almost identical antitissue antibody patterns and very similar clinical manifestations of the disease in these patients are inter-related in some way. The two following speculations may te advanced concerning the phenomenon:

(1) Similar antibodies suggest a similar immunological mechanism under the influence of which like clinical manifestations originated. There are, however, observations suggesting that circulating antibodies in SLE are not the primary cause of tissue destruction. For instance, after entering the foetus during pregnancy, they generally do not cause disease (Bridge and Foley, 1954). Transfusion of plasma of SLE patients into test animals and humans has not produced tissue damage (Bencze, Tiboldi, and Lakatos, 1963; Marmont, 1965). It seems, however, that circulating antitissue antibodies may be indirectly an important causative agent in tissue destruction in SLE, combining with liberated tissue antigens to form soluble complexes which become sedimented from the circulation in the vascular walls and renal glomeruli (Tan, Schur, Carr, and Kunkel, 1966; Koffler, Schur, and Kunkel, 1967). But this mechanism is hardly capable of causing all the manifestations of the disease and it presupposes, moreover, a degree of earlier tissue destruction. It has been observed, for instance, that the LE-factor reacts only with damaged cells (Rapp, 1962; Lachmann, 1961).

(2) A perhaps more natural explanation is that the same disease of concurrent onset in genetically identical patients has caused similar tissue damage which, in turn, has produced similar circulating antitissue antibody patterns because the immune response and the fixation of the antibodies in the tissue antigens have been alike. Additional light on this question might be obtained by finding out whether antitissue antibody titres are different in monozygotic twins who display different clinical manifestations and, on the other hand, whether they are similar in dizygotic twins with a similar disease picture.

\section{Summary}

The course of systemic lupus erythematosus and its clinical manifestations in a pair of monozygotic twins were highly similar. The patterns of circulating antitissue antibodies to several tissue antigens were also similar both qualitatively and quantitatively.

This work was supported by grants from The National Research Council for Medical Sciences and the Sigrid Jusèlius Foundation.

\section{References}

Bencze, G., Tiboldi, D., and Lakatos, L. (1963) Acta rheum. scand., 9, 209 (Experiments on the pathogenetic role of the L.E. factor in dogs and guinea pigs).

Blumenfeld, H. B., Kaplan, S. B., Mills, D. M., and Clark, G. M. (1963) J. Amer. med. Ass., 185, 667 (Disseminated lupus erythematosus in identical twins).

Bridge, R. G., AND Foley, F. E. (1954) Amer. J. med. Sci., 227, 1 (Placental transmission of the lupus erythematosus factor).

Brunjes, S., Zike, K., AND Julian, R. (1961) Amer. J. Med., 30, 529 (Familial systemic lupus erythematosus: Review of the literature, with a report of ten additional cases in four families).

Davis, M. W., AND Gutridge, G. H. (1951) J. Mo. med. Ass., 48, 446 (Disseminated lupus erythematosus in identical twin sisters associated with diabetes mellitus in one case).

Friou, G. J. (1967) In 'Laboratory Diagnostic Procedures in the Rheumatic Diseases', ed. A. S. Cohen, p. 114. Little, Brown, Boston.

GeRY, I., AND DAVIES, A. M. (1961) J. Immunol., 87, 351 (Organ specificity of the heart. I. Animal immunization with heterologous heart).

Jokinen, E. J., AND Julkunen, H. (1965) Ann. rheum. Dis., 24, 477 (DNA haemagglutination test in the diagnosis of systemic lupus erythematosus).

Joseph, R. R., AND Zarafonetis, C. J. D. (1955) Amer. J. med. Sci., 249, 190 (Fatal systemic lupus erythematosus in identical twins: Case reports and review of the literature).

Koffler, D., SChUR, P. H., AND KunKel, H. G. (1967) J. exp. med., 126, 607 (Immunological studies concerning the nephritis of systemic lupus erythematosus).

LACHMANN, P. J. (1961) Immunology, 4, 153 (An attempt to characterize the lupus erythematosus cell antigen).

LeONHARDT, T. (1964) Acta med. scand., Suppl. 416 (Family studies in șystemic lupus erythematosus). 
Lieberman, E., Heuser, E., Hanson, V., Kornreich, H., Donnell, G. N., and Landing, B. H. (1968) Arthr. and Rheum., 11, 22 (Identical 3-year-old twins with disseminated lupus erythematosus: One with nephrosis and one with nephritis).

Marmont, A. M. (1965) Ann. N.Y. Acad. Sci., 124, 838 (The transfusion of active LE plasma into nonlupus recipients, with a note on the LE-like cells).

RAPP, F. (1962) J. Immunol., 88, 732 (Localization of antinuclear factors from lupus erythematosus sera in tissue culture).

RoITt, I. M., AND DonIACH, D. (1958) Lancet, 2, 1027 (Human auto-immune thyroiditis: Serological studies).

TAN, E. M., Schur, P. H., CARR, R. I., AND Kunkel, H. G. (1966) J. clin. Invest., 45, 1732 (Deoxyribonucleic acid (DNA) and antibodies to DNA in serum of patients with systemic lupus erythematosus).

U.S. Department of Health, Education, and Welfare (1959) 'Serologic Tests for Syphilis, 1959 Manual'. USPHS Publication No. 411. U.S. Government Printing Office, Washington, D.C.

Wagenhals, C. O., AND Burgeson, P. A. (1958) N.Y. St.J. Med., 58, 98 (Systemic lupus erythematosus in identical twins). 